DOI https://doi.org/10.30525/978-9934-588-81-5-2.4

\title{
ТЕОРЕТИКО-МЕТОДОЛОГІЧНІ ПІДХОДИ ДО НАДАННЯ МЕДИКО-ПСИХОЛОГІЧНОЇ РЕАБІЛІТАЦІЇ МЕДИЧНИМ ПРАЦІВНИКАМ, ЩО НАДАЮТЬ МЕДИЧНУ ДОПОМОГУ ХВОРИМ НА ГОСТРУ РЕСПІРАТОРНУ ХВОРОБУ СОVID-19
}

\author{
Божук Б. С. \\ кандидат медичних наук, \\ генеральний директор \\ Державний заклад «Спеціалізований (спеиіальний) санаторій \\ «Приморський» Міністерства охорони здоров'я Украӥни», \\ доцент кафедри прикладної медииини \\ Університет «КРОК», \\ президент \\ ВГО «Українська асоиіація лікарів-психологів» \\ м. Київ, Україна
}

Негативно впливати на людство і кожну особистість зокрема може суттєвий спалах будь-якої інфекційної хвороби, особливо з високою контагіозністю та вираженим рівнем смертності, однак існуюча пандемія COVID-19 через свою новизну та невивченість, мало вивчений клінічний перебіг хвороби, неоднозначність підходів до лікування та значну увагу засобів масової інформації, пов'язані з ним чутки, фейки та цілеспрямовану дезінформацію призвів до ще більш значного впливу на психіку населення планети, що спровокувало ще суттєвіші прояви дистресу, тривоги, депресивних розладів, невротичних розладів. Професори Чабан О.С. та Хаустова О.О. приводять результати дослідження та описують широкий спектр психологічних наслідків, до яких може призвести спалах COVID-19 серед яких можна виокремити 3 основні групи:

- поява нових психіатричних симптомів в осіб, які не мають психічних захворювань;

- погіршення стану тих, хто вже страждає на такі -захворювання;

- дистрес у доглядальників за пацієнтами з психічними та соматичними недугами [3] (зокрема і медичні працівники).

Wang C. зі співавторами провели дослідження з вибіркою понад 1 тис. респондентів із різних міст Китаю, під час початкової фази спалаху COVID-19, відповідно до якого 53,8 \% респондентів оцінили психологічний вплив спалаху як середній або тяжкий; 16,5 \% - повідомили про помірні та тяжкі симптоми депресії; 28,8 \% - про симпто- 
ми середньої та тяжкої тривожності та 8,1 \% - про рівень помірного та сильного стресу [7].

Генеральний секретар ООН в своєму виступі навесні 2020 року зазначив, що психічне здоров'я лежить в основі людської природи, а психічні наслідки пандемії супроводжуватимуть світ набагато довше за фізичні. Однак, система психічного здоров'я вже довгі роки залишається недофінансованою у всьому світі.

Медичні працівники є одними 3 найвразливіших груп населення, оскільки стоять на передньому краї боротьби 3 пандемією, надаючи медичну допомогу пацієнтам 3 коронавірусною пневмонією. А отже i вплив на їхнє психічне здоров'я є одним з найінтенсивніших, при цьому вплив на безпосердньо залучених медиків $є$ більшим в порівнянні 3 працівниками які залучені опосередковано. Зокрема $є$ результати китайського дослідження (Xing J. Зі співаторами), що середні значення для чинників (соматизація, обсесивність-компульсивність, тривожність, фобічна тривожність та психотизм) були доказово більшими у медичного персоналу, що безпосередньо контактують з хворими [8].

Дослідження емоційного стану медичних працівників, що працюють безпосередньо з інфікованими пацієнтами ( Dai Y. та співавторами (2020)) показали, що 39,1\% медиків опитаних зазнали суттєвих психологічних проблем [4]. За результатами дослідження Huang, Y. I Zhao, N. серед волонтерів, які працювали з хворими та/або в осередку епідемічної ситуації 34,0\% мали генералізований тривожний розлад, $18,1 \%$ - депресивні розлади, 18,1\% порушення сну [5]. За даними наведеними Циганенко Г. В. та Великодною М. С. отриманими на основі аналізу відповідей на платформі WeChat медиків, що працюють 3 хворими на COVID-19 (Liu S. \& співавтори, 2020) показав, що 50,7\% мають високий рівень прояву симптомів депресії, 44,7\% - тривожності, порушення сну мали $36,1 \%$, а симптоми, пов'язані зі стресом спостерігалися у 73,4\% [2,6]. Серед додаткових причин більшого впливу на медиків можна визначити загрозу власної смерті у будьякий час, стресові умови праці, нехватка та нерівномірність сну, високий рівень відповідальності. Особливого впливу цих чинників зазнають медичні сестри. Зокрема, за даними Чабана О.С. та Хаустової O.O. 85,37 \% медсестер залучених до надання допомоги пацієнтам із COVID-19 були виявлені емоційні реакцї [1].

В Україні існує Наказ Міністерства внутрішніх справ України від 18.08.2014 № 831 «Про затвердження Порядку організації медичного забезпечення в системі Державної служби України з надзвичайних ситуацій» який, поміж іншого, визначає «надання своєчасної медичної допомоги рятувальникам та проведення їх медико-психологічної реабілітації, що здійснюються закладами охорони здоров'я ДСНС Украї- 
ни.» Окремий розділ даного наказу присвячений організації медикопсихологічної реабілітації, яку визначають як комплекс лікувальнопрофілактичних, реабілітаційних та оздоровчих заходів, спрямованих на відновлення психофізіологічних функцій, оптимальної працездатності, соціальної активності рятувальників аварійно-рятувальних служб (формувань), осіб, залучених до виконання аварійнорятувальних робіт у разі виникнення надзвичайної ситуації, а також постраждалих внаслідок такої надзвичайної ситуації. Відповідно до нього, рятувальники, які брали безпосередню участь у проведенні аварійно-рятувальних та інших невідкладних робіт або залучалися до цілодобового чергування, пов'язаного з ліквідацією наслідків надзвичайної ситуації, мають право один раз на рік пройти безоплатно курс медико-психологічної реабілітації строком не менш як 14 діб. А рятувальники, які були травмовані або брали участь у рятувальних заходах пов'язаних із загибеллю людей, зобов'язані пройти відповідне лікування та реабілітацію в центрах медико-психологічної реабілітації [3].

$\mathrm{B}$ той же час, медичні працівники, які і поза пандемією $є$ однією 3 набільш вразливих груп працівників щодо професійного вигорання та інших розладів пов'язаних зі стресом, які щоденно рятують життя та найчастіше зустрічаються зі смертю і при цьому мають одні з найнижчих заробітків, які стоять на передовій боротьби з коронавірусною хворобою та зазнають як психічного так і фізичного впливу, не мають жодної державної програми з медико-психологічної реабілітації та санаторно-курортного лікування.

Ми вважаємо, що така ситуація має бути вирішена найближчим часом. Наше бачення, підтримане професійною Всеукраїнською громадською організацією «Українська асоціація лікарів-психологів» полягає в наступному:

Має бути створений порядок медико-психологічної реабілітації медичних працівників, а на пілотному етапі - медико-психологічної реабілітації медичних працівників, що надають медичну допомогу хворим на гостру респіраторну хворобу COVID-19;

Медичних працівників, що мають безпосередній професійний контакт 3 хворими на COVID-19 та тих, робота яких супроводжувалася смертю пацієнта зобов'язати пройти безоплатну медико-психологічну реабілітацію не рідше разу на рік, а іншим медичним працівникам 3 даної категорії - надати право безоплатного ії проходження.

Для виконання даної програми вбачаємо доцільним перепрофілювати декілька санаторних закладів Міністерства охорони здоров'я України під надання медико-психологічної реабілітації медичних працівників. 


\section{Література:}

1. Наказ Міністерства внутрішніх справ України від 18.08.2014 № 831 «Про затвердження Порядку організації медичного забезпечення в системі Державної служби України з надзвичайних ситуацій» URL: http://www.zakon.rada.gov.ua/laws/show/z1095-14\#Text

2. Циганенко Г. В., Великодна М. С. Надання психологічної допомоги вразливим групам населення під час та після карантину через пандемію COVID-19 : Практичний посібник для психологів і фахівців соціальної роботи [Електронне видання] /Київ ; Кривий Ріг : Вид. Р. А. Козлов, 2020. - 100 с.

3. Чабан О.С., Хаустова О.О. Психічне здоров'я в період пандемії COVID-19 (особливості психологічної кризи, тривоги, страху та тривожних розладів) НейроNEWS: психоневрологія та нейропсихіатрія, № 3 (114), 2020., с. 26-36 -

4. Dai, Y., Hu, G., Xiong, H., Qiu, H., \& Yuan, X. (2020). Psychological impact of the coronavirus disease 2019 (COVID-19) outbreak on healthcare workers in China. medRxiv. doi: 10.1101/2020.03.03.20030874

5. Huang, Y., \& Zhao, N. (2020). Generalized anxiety disorder, depressive symptoms and sleep quality during COVID-19 epidemic in China: a webbased cross-sectional survey. medRxiv. doi: 10.1101/2020.02.19.20025395 5

6. Liu, S., Yang, L., Zhang, C., Xiang, Y.-T., Liu, Z., Hu, S., \& Zhang, B. (2020). Online mental health services in China during the COVID-19 outbreak. The Lancet Psychiatry. doi:10.1016/s2215-0366(20)30077-8 7

7. Wang C., Pan R., Wan X. et al. Immediate psychological responses and associated factors during the initial stage of the 2019 coronavirus disease (COVID-19) epidemic among the general population in China. International Journal of Environmental Research and Public Health. 2020 Jan. Vol. 17, № 5. P. 1729. 2

8. Xing J., Sun N., Xu J. et al. Xu were co-corresponding J. Study of the mental health status of medical personnel dealing with new corona-virus pneumonia. 2020. (Preprint. doi: https://doi.org/10.1101/ 2020.03.04.20030973). 